\title{
PEMBUATAN VIDEO PEMBELAJARAN MELALUI METODE PROJECT BASED LEARNING UNTUK MENINGKATKAN KEMAMPUAN KOMPETENSI GURU DI SMP NANYANG ZHI HUI DIMASA PANDEMI COVID-19
}

\author{
Arthalina Romauli Sinaga ${ }^{1}$ \\ arthalinasinaga@gmail.co \\ Dinas Pendidikan Kota Medan ${ }^{1}$
}

\begin{abstract}
Abstrak
Tujuan penelitian ini adalah Untuk mengobservasi dan mengevaluasi video pembelajaran melalui metode PBL dapat meningkatkan kompetensi guru di SMP Nanyang Zhi Hui Medan di masa Pandemi Covid-19. Untuk mengobservasi dan mengevaluasi apakah metode PBL dapat meningkatkan kompetensi guru di SMP Nanyang Zhi Hui Medan di masa Pandemi Covid-19. Untuk mengobservasi dan mengevaluasi video pembelajaran melalui metode PBL dapat meningkatkan kompetensi guru di SMP Nanyang Zhi Hui Medan di masa Pandemi Covid-19. Untuk mengobservasi dan mengevaluasi apakah metode PBL dapat meningkatkan kompetensi guru di SMP Nanyang Zhi Hui Medan di masa Pandemi Covid-19. Pembuatan video pembelajaran melalui metode PBL dapat meningkatkan kompetensi guru di SMP Nanyang Zhi Hui Medan di masa Pandemi Covid-19.
\end{abstract}

Kata Kunci: Pembuatan Video Project Based Learning Pandemic 


\section{BAB I \\ PENDAHULUAN}

\section{A.Latar Belakang Masalah}

Dimasa pandemi Covid-19 ini guru-guru dituntut untuk lebih kreatif dan inovatif dalam membuat metode pembelajaran bagi siswa karena mereka belum melaksanakan pembelajaran di sekolah. Namun tidak semua guru-guru dapat membuat video pembelajaran di rumah. Sebagai contoh disekolah-sekolah yang ada di kota Medan. Mereka mengambil media pembelajaran dari youtube dan mengirimkannya ke siswa. Ada juga guru yang memberikan materi lewat grup WA dan mengirimkannya kepada siswa dan feedbacknya siswa disuruh ke sekolah untuk memberikan tugas yang sudah selesai. Ada juga guru yang membuat pembelajaran dengan aplikasi zoom tanpa ada video pembelajaran sehingga mulai video zoom dibuka hingga selesai maka tidak ada video pembelajaran yang diberikan.

Berangkat dari permasalahan diatas maka penulis mencoba memberikan metode Project Based Learning (PBL) kepada guru-guru. Metode ini adalah metode pembelajaran yang melihat masalah dan memberikan solusinya.

Untuk mendukung penelitian ini, penulis memperoleh beberapa hasil penelitian sebelumnya.

a) Elfahmi (2020:45) Hasil penelitian menunjukkan Pemahaman Guru-guru di SMA Negeri 3 Seunagan dalam pembelajaran Daring sesuai dengan tuntutan Pemerintah di masa Pandemi Covid-19 yang mewajibkan Guru untuk melaksanakan pembelajaran secara Daring sudah dilaksanakan dan dijalankan dengan baik di SMA Negeri 3 Seunagan. Hasil penelitian menunjukkan bahwa pada Siklus I, pemahaman guru dalam pembelajaran Daring yang dilakukan selama proses pembelajaran di SMA Negeri 3 Seunagan didapat jumlah 1.260. Nilai rata-rata 37, dengan persentase 77,20\%. Dengan demikian pemahaman Guru -guru di SMA Negeri 3 Seunagan dalam kategori Cukup Baik. Kemudian meningkat setelah pelaksanaan Siklus II Pembelajaran Daring yang dilakukan selama proses pembelajaran di SMA Negeri 3 Seunagan didapat jumlah 1.339. Nilai rata-rata 39, dengan persentase 82,04\%. Dengan demikian pemahaman Guru-guru di SMA Negeri 3 Seunagan dalam kategori Baik. Hasil penelitian menunjukkan pemahaman Guru dalam Pembelajaran Daring di SMA Negeri 3 Seunagan dalam kategori baik. 
b) Suciati (2020: 79) Hasil penelitian ini menunjukkan bahwa model pembelajaran daring dapat mengatasi pelaksanaan pembelajaran di masa pademi covid 19 melalui kreatifitas dan inisiatif guru dalam mengelola pembelajaran di rumah. Kreatif itas dan inisiatif guru mengalami peningkatan dalam pembuatan RPP sebesar 18\%, pengelolaan pembelajaran daring sebesar $12 \%$, keaktifan siswa sebesar $17 \%$ dan nilai belajar siswa sebesar $9,6 \%$ dari siklus I ke siklus II dalam pembelajaran. Setelah ada tindakan kompetensi guru secara aktif, kreatif dan inisiatif dalam melaksanakan pembelajaran dirumah, pembelajaran dapat berjalan dengan lancar dalam mengahadapi wabah pandemi covid 19.

Kedua penelitian diatas menunjukkan bahwa model pembelajaran daring menjadi solusi di masa Pandemi Covi-19. Kedua penelitian di atas membuat model pembelajaran daring tanpa memberikan jenis metode pembelajaran apa yang diberikan kepada guru-guru. Berbeda dengan penelitian yang akan difokuskan pada penelitian ini. Penulis memfokuskan membuat video pembelajaran kepada guru-guru untuk menghilangkan rasa jenuh siswa belajar dimasa Pandemi Covid-19. Selanjutnya penulis akan menerapkan metode PBL pada penelitian ini. Objek penelitiannya juga tidak sama. Dikarenakan pnelitian ini dilakukan oleh pengawas maka objek penelitian ini akan berfokus kepada guru-guru di SMP Nanyang Zhi Hui Medan. Instrument yang akan digunakan berupa tes pembuatan video online kepada guru-guru SMP Nanyang Zhi Hui Medan. Data penelitian ini akan diperoleh dari hasil pembuatan video pembelajaran yang dibuat oleh guru-guru di SMP Nanyang Zhi Hui Medan.

Menurut Nurhadi (2004:65), PBL adalah kegiatan berinteraksi antara stimulus dan respons, adanya hubungan antara dua arah belajar dan lingkungan”. Lingkungan memberikan masukan kepada siswa berupa bantuan dan masalah, sedangkan sistem saraf otak berfungsi menafsirkan bantuan itu secara efektif sehingga yang dihadapi dapat diselidiki, dinilai, dianalisis, serta dicari pemecahannya dengan baik. PBL merupakan sebuah pendekatan pembelajaran yang menyajikan masalah konstektual sehingga merangsang siswa untuk belajar. PBL merupakan suatu model pembelajaran yang menantang siswa untuk belajar, bekerja secara berkelompok untuk mencari solusi dari permasalahan dunia nyata. Masalah ini digunakan untuk mengikat siswa pada rasa ingin tahu pada pembelajaran yang dimaksud.

Dari pemahaman diatas maka dapat dilihat bahwa metode PBL adalah metode pembelajaran yang memfokuskan bagaimana permasalahan yang dihadapai saat ini. Hanya perbedaanya diatas memfokuskan stimulus antara guru dan siswa, namun dipenelitian ini guru 
diganti dengan pengawas dan siswa diganti dengan guru-guru. Interaksi antara guru-guru dan pengawas akan terjadi pada kegiatan PBL ini. Guru-guru akan berkelompok berdiskusi dan mengobservasi beberapa permasalahan tentang video pembelajaran yang akan menjadi bahan pembelajaran kepada siswa. Beberapa video pembelajaran ini akan diberikan oleh pengawas kepada guru sebagai referensi guru untuk membuat video pembelajaran di sekolah. Kedua penelitian diatas menunjukkan bahwa PBL sangat efektif dilaksanakan di sekolah sehingga penulis ingin mengaplikasikan metode PBL ini kepada guru-guru.

Sebelum terjadinya Pandemi Covid-19 beberapa peneliti juga sudah membuat penelitian mengenai PBL ini. Yulianti dan Gunawan (2019:406) memperoleh Hasil analisis data dengan program spss 17.00 menunjukkan bahwa terdapat pengaruh penerapan model pembelajaran problem based learning terhadap pemahaman konsep dan berpikir kritis peserta didik. Nilai gain pemahaman konsep kelas eksperimen sebesar 0,51 dan nilai gain kelas kontrol sebesar 0,31 sedangkan nilai gain berpikir kritis kelas eksperimen sebesar 0,58 dan nilai gain kelas kontrol sebesar 0,31. Efektivitas penggunaan model PBL lebih efektif dalam meningkatkan pemahaman konsep dan berpikir kritis peserta didik, ditunjukkan dengan nilai effect size pemahaman konsep sebesar 0,36 dan nilai effect size berpikir kritis sebesar 0,66. Selain itu berdasarkan hasil uji manova, baik nilai signifikansi pemahaman konsep maupun nilai signifikansi kurang dari 0,005 sehingga dapat disimpulkan bahwa terdapat pengaruh penerapan model PBL terhadap pemahamman konsep dan berpikir kritis peserta didik SMA.

Ramadani (2019:84-85) Hasil observasi peneliti terhadap proses pembelajaran materi pencemaran lingkungan dengan mengunakan model pembelajaran Problem Based Learning pada siklus II, terlihat semagat siswa untuk berpikir dan memecahkan masalah semakin bertambah, mereka secara aktif berdiskusi, dalam memecahkan masalah suasana kelas mulai menyenangkan dan siswa mulai tertarik mengikuti pembelajaran dengan mengunakan metode Problem Based Learning . Berdasarkan data hasil tes belajar siswa pada setiap siklus,seperti yang tertera dalam tabel di atas, dapat dikatakan hasil pembelajaran materi pencemaran lingkungan dengan mengunakan metode Problem Based Learning menujukkan adanya peningkatan hasil belajar siswa secara kuantitatif dan kualitatif.

\section{B. Identifikasi Masalah}

Dari uraian sebagaimana dijelaskan pada latar belakang masalah di atas, dapat didentifikasi beberapa permasalahan yang muncul terkait kegiatan pembelajaran pada masa Covid-19, yaitu : 
1. Kurangnya kreatifitas guru-guru SMP Nanyang Zhi Hui di Medan untuk membuat video pembelajaran pada masa Covid-19.

2. Metode PBL ini akan berfokus kepada pembuatan video bahan ajar kepada siswa SMP Nanyang Zhi Hui. Metode pembelajaran ini dimaksudkan agar siswa SMP Nanyang Zhi Hui dapat memahami materi bahan ajar yang disampaikan kepada siswa dan juga guru-guru dapat membuat video pembelajaran yang kreatif dimasa Pandemi Covid-19.

\section{Rumusan Masalah}

Dari latar belakang masalah di atas, maka dapat ditentukan rumusan masalah dari pelaksanaan kegiatan penelitian tindakan sekolah ini yaitu :

1. Apakah pembuatan video pembelajaran melalui metode PBL dapat meningkatkan kompetensi guru di SMP Nanyang Zhi Hui Medan di masa Pandemi Covid-19?

2. Apakah metode PBL dapat meningkatkan kompetensi guru di SMP Nanyang Zhi Hui Medan di masa Pandemi Covid-19?

\section{D.Tujuan}

Tujuan penelitian ini adalah:

Untuk mengobservasi dan mengevaluasi video pembelajaran melalui metode PBL dapat meningkatkan kompetensi guru di SMP Nanyang Zhi Hui Medan di masa Pandemi Covid-19. Untuk mengobservasi dan mengevaluasi apakah metode PBL dapat meningkatkan kompetensi guru di SMP Nanyang Zhi Hui Medan di masa Pandemi Covid-19.

\section{E. Manfaat Penelitian}

1.Bagi guru

Untuk meningkatkan kompetensi guru di SMP Nanyang Zhi Hui Medan di masa Pandemi Covid-19.

2.Bagi sekolah

Untuk meningkatkan kualitas pembelajaran di SMP Nanyang Zhi Hui Medan di masa Pandemi Covid-19. 


\section{BAB II}

\section{TINJAUAN PUSTAKA}

\section{A. Metode Pembelajaran Project Based Learning}

Model pembelajara adalah sistem, yang terdiri dari beberapa komponen yang saling berhubungan satu sama lainnya. Rusman, (2010). Modelpembelajaran problem based learning (PBL) adalah pembelajaran yang memfikuskan pada kegiatan pemecahan masalah. Dasa (2010). Dari pengertian diatas dapat disimpulkan bahwa peserta dalam PBL secara aktif mampu memecahkan masalah pembelajaran dimasa Pandemic Covid19 ini dengan memberikan pembelajaran daring. yang di berikan pendidik kepada siswa. Dalam hal ini pendidik sebagai mediator dan fasilitator untuk membantu peserta didik dalam memahami materi pembelajaran. (Siregar, 2016).

Menurut Dutch dalam Amar(1994) PBL adalah metode instruksional yang menantang peserta didik agar "belajar danuntuk belajar", bekerja sama dengan kelompok untuk mencari solusi bagi masalah yang nyata. Masalah ini di gunakan untuk mengaitkan rasa keingintahuan serta kemampuan analisis peserta didik dan inisiatif atas materi pembelajaran. PBL mempersiapkan peserta didik untuk berpikir kritis dan analitis, dan untuk mencari serta menggunakan sumber pelajaran yang sesuai. Dalam arti peserta didik disini akan berfungsi sebagai guru dan pendidiknya adalah pengawas.

\section{Table.1 Langkah-Langkah Pembelajaran Based Learning}

\begin{tabular}{|c|l|l|l|}
\hline No. & \multicolumn{1}{|c|}{ Indikator } & \multicolumn{3}{|c|}{ Kegiatan Guru } \\
\hline 1. & Orientasi didik pada masalah & $\begin{array}{l}\text { Menjelaskan tujuan pembelajaran, menjelaskan } \\
\text { logistikyang diperlukan, dan memotivasi guru } \\
\text { pada kegiatan pembuatan video pembelajaran. }\end{array}$ \\
\hline 2. & $\begin{array}{l}\text { Bersama mengorganisasi } \\
\text { guru untuk belajar membuat } \\
\text { video pembelajaran. }\end{array}$ & $\begin{array}{l}\text { Membantu peserta mendefiniskan dan } \\
\text { mengorganisasi tugas belajar yang berhubungan } \\
\text { dengan pembuatan video belajar. }\end{array}$ \\
\hline 3. & $\begin{array}{l}\text { Membimbing pengalaman } \\
\text { secara individu } \\
\text { kelompok dan }\end{array}$ & $\begin{array}{l}\text { Menstumulus guru-guru untuk mengumpulkan } \\
\text { video-video pembelajaran yang sudah ada dan } \\
\text { melatih mereka untuk membuat video pembelajaran } \\
\text { dari hasil karya mereka sendiri. }\end{array}$ \\
\hline 4. & $\begin{array}{l}\text { Mengembangkan hasil karya } \\
\text { Mengevaluasi guru-guru mempersiapkan video } \\
\text { pembelajaran mereka. }\end{array}$ \\
\hline
\end{tabular}




\begin{tabular}{|c|lr|l|}
\hline 5. & $\begin{array}{l}\text { Menganalisis } \\
\text { mengevaluasi proses. }\end{array}$ & dan & $\begin{array}{l}\text { Membantu guru-guru mengevaluasi hasil pembuatan } \\
\text { video pembelajaran. }\end{array}$ \\
\hline
\end{tabular}

\section{Kelebihan Model Pembelajaran PBLsebagai berikut:}

a. Pemecahan masalah dalam PBL cukup bagus untuk memahami isi pelajaran

b. Pemecahan masalah berlangsung selama proses pembelajaran menantang kemampuan peserta sertamemberikan kepuasan kepada peserta.

c. PBL dapat meningkatkan aktivitas pembelajaran.

d. Membantu proses transfer siswa untuk memahami masalah-masalah dalam kehidupan sehari-hari.

e. Membantu peserta mengembagkan pengetahuannya dan membantu peserta untuk bertanggung jawab ataspembelajarannya sendiri.

f. Membantu peserta untuk memahami hakekat belajar online sebagai cara berfikir bukan hanya sekedar mampu membuat media pembelajaran melalui WA.

g. PBL menciptakan lingkungan belajaryang menyenangkan dan di sukai peserta didik.

h. Memungkinkan aplikasi dalam dunianyata.

i. Merangsang siswa untuk belajar.

\section{Kekurangan Model Pembelajaran PBL sebagai berikut:}

a. Apabila siswa mengalami kegagalan atau kurang percaya diri dengan minat yang rendah maka siswa enggan untuk mencoba lagi.

b. PBL membutuhkan waktu yang cukup untuk persiapan.

c. Pemahaman yang kurang tentang mengapa masalah-masalah yang di pecahkan maka siswa kurang termotivasi untuk belajar.

\section{B. Video Pembelajaran Online}

Video pembelajaran online adalah metode pembelajaran dimasa pandemic Covid-19. Semua pendidik mulai dari tingkat dasar hingga perguruan tinggi saat ini sudah melakukan pembelajran dengan menggunakan video pembelajaran. Awalnya metode ini diprakarsai oleh Bretz (1971). Dia menemukan tujuh klasifikasi media pembelajaran. 1. Media audio, 2.Media Visual diam, 3. Media visual gerak, 4. Media audio semi gerak, 5.Media visual semi gerak, 6. Media audio visual gerak, 7. Media audio visual diam. Semakin berkembangnya jaman hingga 
tahun 2020 saat masa pandemic datang maka ketujuh media pembelajaran online tadi dikembangkan menjadi beberapa klasifikasi oleh para ahli komputer.

Media pembelajaran online ini dapat dibagi menjadi: 1. video cerita, 2. video dokumenter, 3. video berita, 4. video presentasi. Kelima media pembelajaran ini sudah diterapkan oleh beberapa guru kepada siswanya. Kuntaro (2019:99) membuat penelitian tentang penggunaan media pembelajaran secara daring. Dalam penelitiannya diperoleh bahwa pembelajaran daring dengan metode pembuatan video sangat efektif dimasa Pandemic Covid19 ini . Handarini (2020:496) memperoleh hasil penelitiannya bahwa video pembelajaran sangat dibutuhkan sebagai pembelajaran daring sebagai upaya Study From Home (SFH) selama Pandemi Covid-19.

\section{Video Cerita}

Video cerita cocok digunakan kepada anak-anak dengan menggunakan media gambar. Sehingga selain mendegar siswa juga dapat membayangkan isi cerita dari pembelajaran yang disampaikan. Materi ini sangat cocok jika guru memberikan materi narrative text kepada siswa. Dengan hadirnya media gambar ataupun boneka dapat membuat siswa menjalankan imajinasinya. Sehingga cerita yang didengar dapat mudah dipahami.

\section{Video Dokumenter}

Video documenter juga diperlukan pada pembelajaran ini. Video documenter dapat diberikan kepada siswa. Pada kegiatan pembuatan video documenter ini materi yang cocok adalah materi pembelajaran Science atau IPA. Dengan menghadirkan video documenter siswa dapat melihat langsung objek materi yang diberikan.

\section{Video Berita}

Video berita adalah media pembelajaran yang memakai berita sebagai alat mengisi materi. Materi berita akan dikombinasikan dengan video pembelajaran yang berupa materi yang dipakai dalam pelajaran sekolah. Biasanya jenis materi ini cocok pada materi pembelajaran Bahasa Indonesia dan Bahasa Inggris.

\section{Video Presentasi}

Video presentasi adalah video pembelajaran dengan membuat slide untuk materi ajar. Diantara video pembelajaran yang sudah diperkenankan diatas video presentasi adalah video pembelajaran yang sangat mudah dibuat. Guru hanya perlu mengetik bahan ajarnya di power poin atau slide dan merekam suara beserta slide yang sudah diberikan. Untuk membuat slide lebih menarik. Guru dapat menyelipkan beberapa gambar menarik sehingga dapat 
English Language Teaching Prima Journal, Vol. 2, No. 2. 2021

e-ISSN: 2686-1526

menstimulus siswa dalam meyerap materi. Hindari pembuatan slide yang menampilkan gambar yang tidak sopan. 


\section{BAB III \\ METODE PENELITIAN}

\section{A. Setting Penelitian}

1. Tempat penelitian

Penelitian ini dilaksankan di SMP Nanyang Zhi Hui Medan, Jln. Abdullah Lubis No. 15 Medan.

2. Waktu penelitian

Penelitian ini dilaksanakan pada tahun pelajaran 2020/2021 selama kurang lebih 3 bulan dari bulan Agustus sampai dengan bulan Oktober 2020

\section{B. Metode Penelitian}

Penulis menggunakan model Kurt Lewin dalam penelitian ini yang terdiri dari empat tahapan yaitu :

1. Perencanaan (Planning)

Secara rinci perencanaan berisi apa yang akan dilakukan beserta rasionalnya, siapa yang akan melakukan, di mana, kapan, dan bagaimana.

2. Tindakan (Acting)

Pada tahap ini, peneliti melakukan tindakan yang merupakan implementasi atau penerapan isi rancangan penelitian tindakan.

3. Observasi (Observing)

Observasi atau pengamatan dimaksudkan untuk mengenali, merekam, mendokumentasikan semua indikator (baik proses maupun hasil) perubahanperubahan yang terjadi baik sebagai akibat tindakan terencana maupun sebagai efek samping.

\section{Refleksi (Reflecting)}

Tahap refleksi melibatkan kegiatan menganalisis, memaknai, menjelaskan dan menyimpulkan. Kegiatan refleksi dapat dipandang sebagai upaya untuk memahami dan memaknai proses dan hasil yang dicapai sebagai akibat dari tindakan yang dilakukan. Pelaksanaan tindakan yang disertai dengan kegiatan pengamatan menghasilkan cerita tentang apa yang terjadi. Berdasarkan informasi ini selanjutnya perlu memikirkan implikasi-implikasi bagi pelaksanaan tindakan yang akan datang. 
Penulis akan memperoleh manfaat perbaikan praktis yang meliputi penanggulangan berbagai masalah belajar guru dan kesulitan mengajar oleh guru dimasa Pandemi Covid-19. Penulis melakukan tindakan untuk mengevaluasi ada tidaknya dampak positif terhadap aplikasi pembuatan video bahan ajar dimasa Pandemi Covid-19 ini, penulis memerlukan kriteria keberhasilan, yang ditetapkan sebelum tindakan dilakukan. Dari kegiatan refleksi ini, diperoleh ketetapan tentang hal-hal yang telah tercapai menjadi bahan dalam merencanakan kegiatan siklus berikutnya.

Adapun bagan desain penelitian tindakan model Kurt Lewin digambarkan sebagai berikut

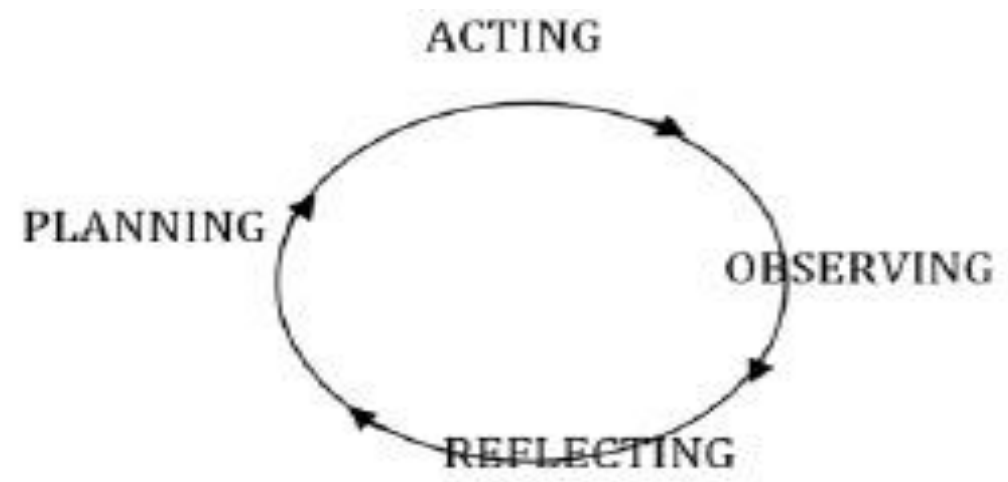

Tindakan penelitian ini dilakukan dalam dua siklus sebab setelah dilakukan refleksi yang meliputi analisis dan penilaian terhadap proses tindakan, akan muncul permasalahan atau pemikiran baru sehingga perlu dilakukan perencanaan ulang pengamatan ulang, tindakan ulang serta dilakukan refleksi ulang.

\section{Subjek Penelitian}

Yang menjadi subjek penelitian adalah para guru SMP Swasta Nanyang Zhi Hui yang berjumlah 15 orang guru sedangkan yang menjadi objek penelitian adalah peningkatan kompetensi guru di SMP Swasta Nanyang Zhi Hui Medan di masa pandemi Covid-19 dalam pembuatan video pembelajaran.

\section{Metode Pengumpulan data}

Teknik pengumpulan data yang digunakan dalam penelitian ini adalah wawancara dan observasi. Instrumen yang digunakan berupa soal pre tes dan post tes. Analisis data terhadap 
hasil belajar siswa dalam pembelajaran pembuatan video pembelajaran. Dianalissis dengan dengan menggunakan analisis deskriptif.

\section{E. Data Penelitian}

Hasil belajar siswa diketahui dari tes masing-masing siklus. Data peningkatan hasil belajar siswa didapat dengan menggunakan selisih yaitu membandingkan rata-rata nilai tes siklus 1 dan tes siklus II. Siklus ke-1 bertujuan untuk mengetahui tingkat pemahaman pembuatan video pembelajaran yang akan diaplikasikan ke semua materi bahan ajar, yang kemudian digunakan sebagai bahan refleksi untuk melakukan tindakan pada siklus ke-2. Sedangkan siklus ke-2 dilakukan untuk mengetahui peningkatan pemahaman konsep pencemaran lingkungan dalam video pembelajaran setelah dilakukan perbaikan terhadap pelaksanaan pembelajaran yang didasarkan pada refleksi siklus ke-2, yang dilanjutkan dengan siklus ke-3. Kesimpulan diambil atas dasar perubahan hasil tes dan non tes antara siklus ke-1 ke siklus berikutnya.

Dari perubahan hasil tes, jika menunjukkan kenaikan positif secara signifikan berarti terjadi peningkatan hasil pembelajaran. Tetapi jika sebaliknya, maka perlu refleksi dan perbaikan pelaksanaan model pembelajaran yang diterapkan antara siklus selanjutnya. Sedangkan perubahan hasil non tes baik dari wawancara, angket maupun jurnal, diungkap apa adanya sesuai hasil yang telah terkumpul sebagai perbandingan antara siklus ke-1 dengan siklus berikutnya. Indikator keberhasilan dalam Penelitian ini adalah: 1.Meningkatkan kompetensi guru untuk membuat video pembelajaran dengan menggunakan metode PBL 2. Berhasilnya guru membuat video pembelajaran yang kreatif untuk meningkatkan hasil belajar siswa di SMP Nanyang Zhi Hui Medan.

\section{F. Langkah-Langkah Pengumpulan Data}

Sebelum melakukan pengumpulan data, pre-test dilakukan untuk mengetahui kemampuan guru SMP Nanyang untuk membuat video pembelajaran. Prosedur pengumpulan data ini dilakukan selama 6 pertemuan melalui dua siklus. Setiap siklus terdiri dari tiga pertemuan. Masingmasing siklus terdiri dari empat tahap. Keempat tahap itu adalah planning, action, observation and reflection.

\section{Siklus 1}


Pada siklus 1, penulis mengobservasi situasi proses pembelajaran yang dilakukan oleh guru-guru di SMP Nanyang. Menginterview guru-guru mengenai metode pembelajaran apa yang mereka lakukan disaat Pandemi Covid-19 ini. Apakah ada masalah saat mereka membuat materi pembelajaran secara daring.

Siklus 1 di penelitian ini dilakukan 4 tahapan yaitu:

\section{Planning}

Planning atau perencanaan untuk melakukan tahap pertama. Dalam kegiatan ini pengawas membuat program pengajaran yang sudah disusun mengenai pembuatan video pembelajaran selama melakukan siklus 1 . Kegiatan yang dilakukan pada siklus 1 ini adalah:

a. Menyiapkan materi bahan ajar pembuatan video pembelajaran setiap pertemuan.

b. Menyiapkan fasilitas mengajar seperti laptop, slide, video.

c. Menyiapkan instrument penelitian, seperti mengobservasi pengajaranan pada proses pembelajaran, interview dan membuat catatan hasil observasi.

d. Menyiapkan pre-tes sebagai instrument untuk mengumpulkan data.

2. Action

Action adalah proses melakukan sesuatu. Kegiatan ini adalah aplikasi dari perencanaan. Dalam kegiatan ini guru-guru diajari bagaimana membuat video pembelajaran sesuai matapelajaran yang dibawakan dikelas.

Table 2. Langkah-Langkah Melakukan Kegiatan di Siklus 1

\begin{tabular}{|c|l|l|}
\hline Pertemuan & Kegiatan Pengawas & Kegiatan Guru-Guru \\
\hline 1 & 1. Pengawas memotivasi guru-guru untuk & 1. Guru mendengarkan \\
& meningkatkan kompetensi mereka dalam & penjelasan pengawas. \\
& memberikan materi ajar selama Covid-19. & 2. Guru mendapatkan materi \\
& 2. Pengawas memperkenalkan bagaimana & pembuatan video bahan ajar \\
& membuat video bahan ajar. & 3. Guru menjawab pertanyaan \\
& 3. Pengawas membuka session pertanyaan & dari pengawas. \\
& tentang materi yang disampaikan. & \\
\hline 2 & 4. Pengawas memberikan Pre-Test kepada & \\
\hline & guru-guru. & \\
\hline
\end{tabular}




\begin{tabular}{|c|c|}
\hline $\begin{array}{l}\text { ajar berupa pembuatan video. Prosedurnya } \\
\text { dapat dilihat dibawah ini: } \\
\text { Sebelum melakukan kegiatan : } \\
\text { 1. Pengawas memberikan istruksi kepada guru- } \\
\text { guru untuk membuat materi bahan ajar } \\
\text { dalam bentuk slide atau power poin. } \\
\text { 2. Memperkenalkan pembuatan video bahan } \\
\text { ajar. Mendownload aplikasi inshoot di } \\
\text { laptop masing-masing atau menyiapkan } \\
\text { tripod untuk mempermudah saat berbicara } \\
\text { didepan kamera handphone. } \\
\text { 3. Merekam suara ataupun keseluruhan tubuh } \\
\text { saat mengajar. } \\
\text { Setelah melakukan kegiatan : } \\
\text { Pengawas memberikan motivasi kepada guru. } \\
\text { Untuk membuat video bahan ajar. } \\
\text { Pengawas memberikan panduan pembuatan } \\
\text { video bahan ajar. }\end{array}$ & $\begin{array}{l}\text { pembuatan materi bahan ajar } \\
\text { dalam bentuk slide atau } \\
\text { power poin. } \\
\text { 2. Guru membuat materi bahan } \\
\text { ajar didalam slide atau power } \\
\text { poin. } \\
\text { 3. Guru merekam suara ataupun } \\
\text { keseluruhan tubuh untuk } \\
\text { melakukan pembelajaran. }\end{array}$ \\
\hline $\begin{array}{l}\text { Pengawas memberikan kesimpulan tentang } \\
\text { materi bahan ajar pembuatan video bahan ajar. } \\
\text { Pengawas membuat post test tentang } \\
\text { pembuatan video bahan ajar. }\end{array}$ & $\begin{array}{l}\text { Guru memahami materi bahan } \\
\text { ajar tentang pembuatan video } \\
\text { bahan ajar dan penggunaan } \\
\text { tripod saat merekam guru saat } \\
\text { berbicara. }\end{array}$ \\
\hline
\end{tabular}

\section{Observasi}

Pada kegiatan observasi, pengawas mengobservasi guru-guru pada saat pembuatan video pembelajaran. Pengawas mencoba melihat bagaimana mereka menggunakan fasilitas seperti tripod, ataupun fasilitas penunjang saat merekam diri mereka saat membuat video pembelajaran. Observasi ini dilakukan disalam kelas dengan tetap menggunakan protocol kesehatan. Tujuan observasi ini dilakukan untuk mengobservasi kondisi selama melakukan proses pembelajaran. 


\section{Reflection}

Reflection adalah proses umpan balik dari kegiatan yang diberikan sebelumnya. Kegiatan reflection dilakukan untuk menganalisis situasi dan membuat kesimpulan. Dalam kegiatan ini pengawas mencoba menganalisis hasil pre test yang sudah dilakukan oleh guruguru di siklus pertama dan menyimpulkan hasil analisis yang didapat. Hasil dari pre test ini adalah tolak ukur untuk kegiatan di siklus 2 untuk melihat peningkatan mereka sebelum siklus 2 dilakukan.

Siklus 2

Kegiatan pada siklus ke-2 mempunyai persamaan siklus 1; planning, action, observation, and reflection. Kegiatan ini adalah kelanjutan dari siklus 1. Dari hasil evaluasi siklus 1 akan berhubungan ke siklus 2. Pada umumnya pada kegiatan siklus ini pengawas akan memperoleh peningkatan kompetensi guru saat membuat video pembelajaran. Pada siklus 2 pengawas akan melakukan kegiatan planning, action, observation and reflection dari hasil siklus 1.

1. Planning

Pada siklus 2 perencanaan dilakukan berdasarkan hasil dari siklus 1. Ada beberapa kegiatan yang dirubah kondisinya pada kegiatan ini:

a. Merevisi menyiapkan perencanaan hasil kegiatan siklus 1 .

b. Menyiapkan media yang dibutuhkan pada proses pembelajaran.

c. Meyiapkan materi video pembelajaran hasil dari kegiatan siklus 1 dan 2 .

\section{Action}

Kegiatan ini adalah hasil dari implementasi siklus 2. Pada kegiatan ini dilakukan tiga pertemuan. Siklus 1 akan berubah dalam upaya peningkatan kompetensi guru untuk membuat video pembelajaran. Kegiatan siklus 2 akan dilakukan seperti dibawah ini:

Table 2. Kegiatan Siklus II 


\begin{tabular}{|c|c|c|}
\hline Pertemuan & Kegiatan Pengawas & Kegiatan Guru-Guru \\
\hline 1 & $\begin{array}{l}\text { Pengawas memotivasi guru-guru untuk } \\
\text { meningkatkan kompetensi mereka dalam } \\
\text { memberikan materi ajar selama Covid-19. } \\
\text { Pengawas memperkenalkan bagaimana } \\
\text { membuat video bahan ajar. } \\
\text { 3. Pengawas membuka session pertanyaan } \\
\text { tentang materi yang disampaikan. } \\
\text { 4. Pengawas memberikan Pre-Test kepada } \\
\text { guru-guru. }\end{array}$ & $\begin{array}{l}\text { 1. Guru mendengarkan } \\
\text { penjelasan pengawas. } \\
\text { 2. Guru mendapatkan materi } \\
\text { pembuatan video bahan ajar } \\
\text { 3. Guru menjawab pertanyaan } \\
\text { dari pengawas. }\end{array}$ \\
\hline 2 & $\begin{array}{l}\text { Pengawas mendemostrasikan pembuatan bahan } \\
\text { ajar berupa pembuatan video. Prosedurnya } \\
\text { dapat dilihat dibawah ini: } \\
\text { Sebelum melakukan kegiatan : } \\
\text { 1. Pengawas memberikan istruksi kepada guru- } \\
\text { guru untuk membuat materi bahan ajar } \\
\text { dalam bentuk slide atau power poin. } \\
\text { 2. Memperkenalkan pembuatan video bahan } \\
\text { ajar. Mendownload aplikasi inshoot di } \\
\text { laptop masing-masing atau menyiapkan } \\
\text { tripod untuk mempermudah saat berbicara } \\
\text { didepan kamera handphone. } \\
\text { 3. Merekam suara ataupun keseluruhan tubuh } \\
\text { saat mengajar. } \\
\text { Setelah melakukan kegiatan : } \\
\text { Pengawas memberikan motivasi kepada guru. } \\
\text { Untuk membuat video bahan ajar. } \\
\text { Pengawas memberikan panduan pembuatan } \\
\text { video bahan ajar. }\end{array}$ & $\begin{array}{l}\text { 1. Guru mendengarkan instruksi } \\
\text { pembuatan materi bahan ajar } \\
\text { dalam bentuk slide atau } \\
\text { power poin. } \\
\text { 2. Guru membuat materi bahan } \\
\text { ajar didalam slide atau power } \\
\text { poin. } \\
\text { 3. Guru merekam suara ataupun } \\
\text { keseluruhan tubuh untuk } \\
\text { melakukan pembelajaran. }\end{array}$ \\
\hline & $\begin{array}{l}\text { Pengawas memberikan kesimpulan tentang } \\
\text { materi bahan ajar pembuatan video bahan ajar. } \\
\text { Pengawas membuat post test tentang }\end{array}$ & $\begin{array}{l}\text { Guru memahami materi bahan } \\
\text { ajar tentang pembuatan video } \\
\text { bahan ajar dan penggunaan }\end{array}$ \\
\hline
\end{tabular}




\begin{tabular}{|l|l|l|}
\hline pembuatan video bahan ajar. & $\begin{array}{l}\text { tripod saat merekam guru saat } \\
\text { berbicara. }\end{array}$ \\
\hline
\end{tabular}

\section{Observation}

Observasi tetap dilakukan pada kegiatan ini. Hanya saja kegiatan ini keberlanjutan dari kegiatan siklus 2 pada proses pembuatan video bahan ajar.

\section{Reflection}

Kegiatn refelection ini adalah keberlanjutan kegiatan hasil dari siklus kedua. Dari kegiatan ini akan mengobservasi hasil kegiatan siklus 1. Jika ada peningkatan yang significan pada kegiatan refelection di siklus kedua ini maka inilah siklus kegiatan pembuatan video yang terakhir.

\section{G. Penilaian Hasil Test}

Bentuk test yang diberikan berupa pelatihan pembuatan video. Ada beberapa criteria yang akan dinilai pada pembuatan video ini. 1) materi yang lengkap dan mudah dipahami, 2) perpaduan warna yang tidak mencolok namun tetap menarik, 3) pencahayaan yang digunakan dalam merekam video, 4) suara yang jelas saat menyampaikan materi, dan 5) penampilan video pembelajaran yang kreatif dan inofatif.

Berikut adalah cara mendapatkan hasil evaluasi dari kedua siklus.

Sudijono (2011:318), merumuskan hasil evaluasi yang dilakukan pada siklus 1. Nilai yang benar dan tertinggi akan mendapatkan nilai 20 dan salah nilai 0. Berikut cara penilaiannya:

$$
\mathbf{S}=\underline{\mathbf{R}} \times \mathbf{1 0 0 \%}
$$

$\mathbf{N}$

$$
\begin{aligned}
\text { Dimana }: & S=\text { Hasil Nilai test } \text { Score of the test } \\
\mathrm{R} & =\text { Jumlah nilai yang benar } \\
\mathrm{N} & =\text { Jumlah pertanyaan }
\end{aligned}
$$

Table 3. Langkah-Langkah Melakukan Kegiatan di Siklus 1

\begin{tabular}{|c|l|l|}
\hline Pertemuan & Kegiatan Pengawas & \multicolumn{2}{|l|}{ Kegiatan Guru-Guru } \\
\hline 1 & Pengawas memotivasi guru-guru untuk & 1. Guru mendengarkan \\
& meningkatkan kompetensi mereka dalam & penjelasan pengawas. \\
& memberikan materi ajar selama Covid-19. & 2. Guru mendapatkan materi \\
\hline
\end{tabular}




\begin{tabular}{|c|c|c|}
\hline & $\begin{array}{l}\text { 1. Pengawas memperkenalkan bagaimana } \\
\text { membuat video bahan ajar. } \\
\text { 2. Pengawas membuka session pertanyaan } \\
\text { tentang materi yang disampaikan. } \\
\text { 3. Pengawas memberikan Pre-Test kepada } \\
\text { guru-guru. }\end{array}$ & $\begin{array}{l}\text { pembuatan video bahan ajar } \\
\text { 3. Guru menjawab pertanyaan } \\
\text { dari pengawas. }\end{array}$ \\
\hline 2 & $\begin{array}{l}\text { Pengawas mendemostrasikan pembuatan bahan } \\
\text { ajar berupa pembuatan video. Prosedurnya } \\
\text { dapat dilihat dibawah ini: } \\
\text { 1. Sebelum melakukan kegiatan : } \\
\text { 2. Pengawas memberikan istruksi kepada } \\
\text { guru-guru untuk membuat materi bahan } \\
\text { ajar dalam bentuk slide atau power poin. } \\
\text { 3. Memperkenalkan pembuatan video } \\
\text { bahan ajar. Mendownload aplikasi } \\
\text { inshoot di laptop masing-masing atau } \\
\text { menyiapkan tripod } \\
\text { mempermudah saat berbicara didepan } \\
\text { kamera handphone. } \\
\text { 4. Merekam suara ataupun keseluruhan } \\
\text { tubuh saat mengajar. } \\
\text { 5. Setelah melakukan kegiatan : } \\
\text { 6. Pengawas memberikan motivasi kepada } \\
\text { guru. Untuk membuat video bahan ajar. } \\
\text { 7. Pengawas memberikan panduan } \\
\text { pembuatan video bahan ajar. }\end{array}$ & $\begin{array}{l}\text { 1. Guru mendengarkan } \\
\text { instruksi pembuatan } \\
\text { materi bahan ajar dalam } \\
\text { bentuk slide atau power } \\
\text { poin. } \\
\text { 2. Guru membuat materi } \\
\text { bahan ajar didalam slide } \\
\text { atau power poin. } \\
\text { 3. Guru merekam suara } \\
\text { ataupun keseluruhan } \\
\text { tubuh untuk melakukan } \\
\text { pembelajaran . }\end{array}$ \\
\hline & $\begin{array}{l}\text { 8. Pengawas memberikan kesimpulan } \\
\text { tentang materi bahan ajar pembuatan } \\
\text { video bahan ajar. } \\
\text { 9. Pengawas membuat post test tentang } \\
\text { pembuatan video bahan ajar. }\end{array}$ & $\begin{array}{l}\text { Guru memahami materi bahan } \\
\text { ajar tentang pembuatan video } \\
\text { bahan ajar dan penggunaan } \\
\text { tripod saat merekam guru saat } \\
\text { berbicara. }\end{array}$ \\
\hline
\end{tabular}




\section{Observasi}

Pada kegiatan observasi, pengawas mengobservasi guru-guru pada saat pembuatan video pembelajaran. Pengawas mencoba melihat bagaimana mereka menggunakan fasilitas seperti tripod, ataupun fasilitas penunjang saat merekam diri mereka saat membuat video pembelajaran. Observasi ini dilakukan disalam kelas dengan tetap menggunakan protocol kesehatan. Tujuan observasi ini dilakukan untuk mengobservasi kondisi selama melakukan proses pembelajaran.

\section{Reflection}

Reflection adalah proses umpan balik dari kegiatan yang diberikan sebelumnya. Kegiatan reflection dilakukan untuk menganalisis situasi dan membuat kesimpulan. Dalam kegiatan ini pengawas mencoba menganalisis hasil pre test yang sudah dilakukan oleh guruguru di siklus pertama dan menyimpulkan hasil analisis yang didapat. Hasil dari pre test ini adalah tolak ukur untuk kegiatan di siklus 2 untuk melihat peningkatan mereka sebelum siklus 2 dilakukan. 


\section{BAB IV}

\section{HASIL PENELITIAN DAN PEMBAHASAN}

\section{A. Deskripsi Data}

Pembahasan mengenai analisis proses pelaksanaan kegiatan pembuatan video pembelajaran melalui metode project based learning di SMP Nanyang Zhi Hui di masa pandemi Covid-19 Tahun Pelajaran 2020/2021 sebagai upaya untuk meningkatkan kemampuan kompetensi guru dalam kegiatan belajar mengajar secara daring maupun luring mengacu pada data utama, teori pada bab II dan hasil penelitian sebagaimana diuraikan di bawah ini.

\section{B. Hasil Penelitian}

\section{Kondisi Awal}

Kegiatan belajar mengajar dilaksanakan secara daring menggunakan Google Meet dengan menggunakan metode ceramah dan siswa mengerjakan tugas yang terdapat pada buku latihan yang ada. Hal ini terjadi karena para guru belum mengetahui cara membuat video pembelajaran sehingga kegiatan belajar mengajar terlaksana kurang menarik.

Hasil kegiatan prasiklus menunjukan bahwa 15 guru Mata Pelajaran yang ada di SMP Nanyang Zhi Hui belum mampu membuat video pembelajaran dengan baik untuk meningkatkan kompetensi guru dalam kegiatan belajar mengajar secara daring.

\section{Pelaksanaan Tindakan Perbaikan Siklus Kesatu}

a. Perencanaan

Perencanaan yang dilakukan pada pelaksanaan kegiatan siklus kesatu meliputi:

1. Mempersiapkan materi ajar yang akan dibuat ke video pembelajaran.

b. Pelaksanaan

Pelaksanaan kegiatan pada siklus kesatu ini adalah sebagai berikut :

1. Pertemuan pertama

1.1 Peneliti dan peserta berdialog sekitar 15 menit mengenai kegiatan pembuatan video pembelajaran.

1.2 Peserta diminta untuk membuat video pembelajaran. 


\section{c. Observasi}

Peneliti melakukan observasi dengan menggunakan lembar observasi yang telah dipersiapkan selama kegiatan pembuatan video berlangsung.

d. Refleksi

Dari hasil observasi maka diperoleh nilai yang dibawah 70 terkendala pada saat merekam video pembelajaran. Ada sebagian guru yang belum memahami pemakaian fasilitas yang sudah ada. Sehingga dapat diperoleh hasil reflection bahwa kegiatan pengambilan test masih dibutuhkan sehingga tidak ada lagi guruguru yang mendapatkan nilai 70 kebawah. Hal ini dapat dilihat pada Tabel 3:

Tabel 4. Hasil Analisis Siklus 1

\begin{tabular}{|c|l|c|}
\hline No. & \multicolumn{1}{|c|}{ Nama Guru } & Nilai Pre-Test \\
\hline 1. & Agnes Fransiska Sagala & 64 \\
\hline 2. & Andani Dwi Ningrum & 50 \\
\hline 3. & Andira Emelita Sinaga & 62 \\
\hline 4. & Baik Baik Zaima & 76 \\
\hline 5. & Fery & 64 \\
\hline 6. & Ita & 56 \\
\hline 7. & Lina & 60 \\
\hline 8. & Margareta & 40 \\
\hline 9. & Michael Li & 70 \\
\hline 10. & Michael Tan & 62 \\
\hline 11. & Netty & 56 \\
\hline 12. & Niarita Ginting & 60 \\
\hline 13. & Wilyo & 54 \\
\hline 14. & Yenni & 64 \\
\hline 15. & Yolanda Theresia & 59,2 \\
\hline Rata-Rata & \\
\hline & & \\
\hline
\end{tabular}

Berdasarkan data diatas, maka diperlukan langkah-langkah perbaikan selanjutnya. Dengan kata lain perlu dilaksanakan siklus kedua sehingga hasil perbaikannya optimal.

\section{Pelaksanaan Tindakan Perbaikan Siklus Kedua}


Pada siklus kedua ini dilkakukan kembali rangkaian kegiatan perencanaan, pelaksanaan, observasi, dan refleksi yang berdasarkan hasil refleksi pada pelaksanaan siklus pertama.

a. Perencanaan

Perencanaan yang dilaksanakan pada siklus kedua ini didasarkan pada hasil refleksi siklus pertama dengan tujuan untuk memperbaiki kegiatan yang kurang berhasil pada siklus pertama, yang meliputi kegiatan-kegiatan sebagai berikut:

1. Mempersiapkan materi ajar yang akan dibuat menjadi video pembelajaran.

2. Mempersiapkan instrumen penelitian berupa (a) Daftar hadir, (b) Naskah materi penelitian, (c) Lembar penilaian dan (d) Pedoman wawancara (diskusi).

b. Penjelasan secara ringkas tentang pelaksanaan kegiatan pada siklus kedua ini sebagai berikut:

1. Peneliti dan peserta melaksanakan kegiatan awal dengan mengisi administrasi kehadiran.

2. Peneliti dan peserta berdialog sekitar 15 menit membahas kelemahan dalam pembuatan video pembelajaran.

3. Peneliti bertindak sebagai narasumber dan menyampaikan langkah-langkah dalam pembuatan video pembelajaran secara garis besar, sebagai berikut:

(1) Menulis skenario yang bertujuan sebagai pemandu kemana arah pembicaraan ketika akan direkam nanti.

(2) Proses rekaman

(3) Cari Ilustrasi

(4) Proses editing

(5) Proses unggah/upload

c. Observasi

Peneliti melakukan observasi dengan menggunakan lembar observasi yang telah dipersiapkan .

d. Refleksi

Berdasarkan hasil observasi pelaksanaan tindakan perbaikan pada siklus kedua menunjukan hasil seperti yang terlihat pada Tabel 4 berikut: 
Tabel 5. Hasil Analisis Siklus 2

\begin{tabular}{|c|l|c|c|}
\hline No. & \multicolumn{1}{|c|}{ Nama Guru } & $\begin{array}{c}\text { Nilai Pre-Test } \\
\text { Siklus 1 }\end{array}$ & $\begin{array}{c}\text { Nilai Pre-Test } \\
\text { Siklus 2 }\end{array}$ \\
\hline 1. & Agnes Fransiska Sagala & 64 & 70 \\
\hline 2. & Andani Dwi Ningrum & 76 & 88 \\
\hline 3. & Andira Emelita Sinaga & 62 & 78 \\
\hline 4. & Baik Baik Zaima & 70 & 84 \\
\hline 5. & Fery & 80 & 90 \\
\hline 6. & Ita & 70 & 74 \\
\hline 7. & Lina & 66 & 88 \\
\hline 8. & Margareta & 72 & 68 \\
\hline 9. & Michael Li & 68 & 86 \\
\hline 10. & Michael Tan & 70 & 88 \\
\hline 11. & Netty & 72 & 84 \\
\hline 12. & Niarita Ginting & 60 & 70 \\
\hline 13. & Wilyo & 60 & 76 \\
\hline 14. & Yenni & 78 & 88 \\
\hline 15. & Yolanda Theresia & & 81,2 \\
\hline Rata-Rata & & \\
\hline
\end{tabular}

Dari hasil pre-test yang diperoleh nilai rata-rata 70 dari siklus 1 dari data diatas maka dapat disimpulkan bahwa nilai tertinggi adalah saat pre test siklus 1 adalah 82, selanjutnya nilai 80, dan yang terendah adalah nilai 62. Dari hasil observasi maka diperoleh maka ada perubahan pencapaian kompetensi pembuatan video di siklus 1, namun begiti masih ada guru yang mendapatkan niali dibawah 70 . Ada 6 orang guru yang mendapatkan nilai $60^{+}$. Maka dapat disimpulkan pengawas perlu melakukan kegiatan siklus 2.

Dari hasi nilai siklus 2 nilai rata-rata post test adalah 81,2 dapat dilihat ada perubahan yang sangat siknifikan pada pembuatan video bahan ajar di SMP Nanyang. Tidak ada lagi guru yang mendapatkan nilai dibawah 70. Keseluruhan guru pada kegiatan ini sudah dapat 
membuat video pembelajaran kepada siswa. Mereka juga sudah dapat memadukan warna yang dapat membuat kegiatan pembelajaran lebih menarik.

\section{Grafik 1. Grafik Peningkatan Kompetensi Guru Pembuatan Video Pembelajaran}

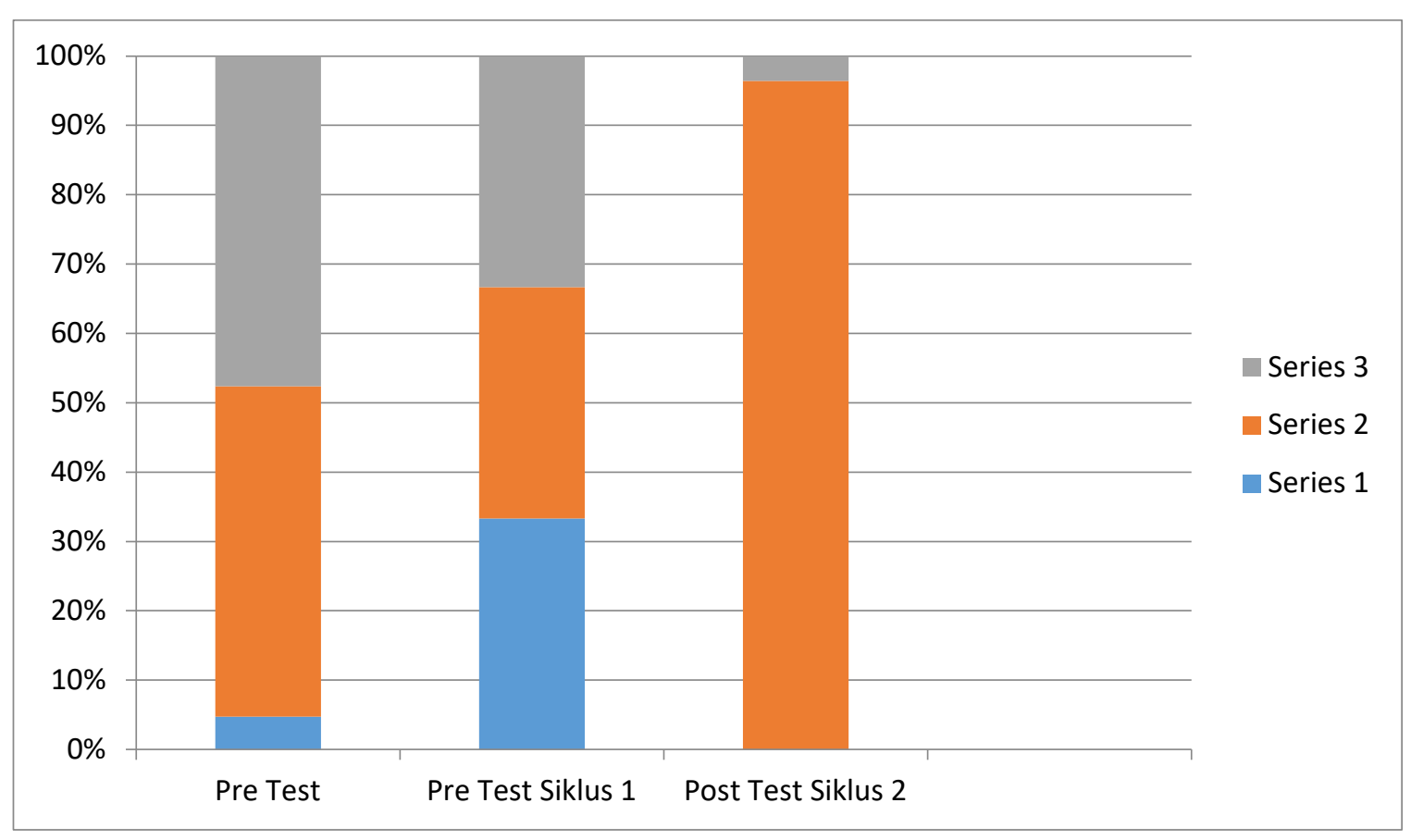

\section{Pembahasan}

Dari gambar grafik diatas dapat dilihat bahwa ada peningkatan kompetensi guru pada kegiatan pre-tes diperoleh 59,2. Hasil nilai siklus satu 70 dan nilai siklus 2, 81,2 sehingga dapat disimpulkan hasil penelitian ini bahwa metode PBL dapat meningkatkan kompetensi guru dalam membuat video bahan ajar dimasa Pandemi Covid-19.

Dari hasil reflection dari kegiatan pembuatan video pembelajaran ini tentunta didapati kendala yang ada dilapangan. Kendala itu berupa jaringan internet yang kurang stabil, sulitnya membuat materi bahan ajar yang dibuat dalam bentuk slide sehingga membutuhkan banyak waktu untuk menyesuaikan bentuk materi dan warna. Namun kunci kegiatan ini adalah kesabaran untuk menghasilkan video pembelajaran yang baik. 


\section{BAB V \\ KESIMPULAN DAN SARAN}

\section{A. Kesimpulan}

Dari hasil data yang diperoleh maka diperoleh kesimpulan:

1. Pembuatan video pembelajaran melalui metode PBL dapat meningkatkan kompetensi guru di SMP Nanyang Zhi Hui Medan di masa Pandemi Covid-19. Kesimpulan ini dapat dilihat pada table dan grafik yang sudah dibahas di bab sebelumya. Dari hasil observasi maka diperoleh maka ada perubahan pencapaian kompetensi pembuatan video di siklus 1, namun begiti masih ada guru yang mendapatkan niali dibawah 70 . Dari hasi nilai siklus 2 nilai rata-rata post test adalah 81,2 dapat dilihat ada perubahan yang sangat siknifikan pada pembuatan video bahan ajar di SMP Nanyang.

2. Metode PBL dapat meningkatkan kompetensi guru di SMP Nanyang Zhi Hui Medan di masa Pandemi Covid-19.

\section{B. Saran}

Berdasarkan hasil penelitian, maka dapat disarankan beberapa hal yaitu sebagai berikut :

1. Guru mata pelajaran hendaknya terus berusaha untuk meningkat kreatifitasnya dalam pembuatan video pembelajaran guna untuk meningkatkan motivasi dan semangat siswa dalam belajar pada masa Covid-19.

2. Kepala sekolah hendaknya memfalitasi guru dalam penyediaan sarana dan prasarana untuk menunjang pembuatan video pembelajaran. 


\section{DAFTAR PUSTAKA}

Amir,M.Taufik.2015.Inovasi Pendidikan Melalui Problem Based Learning. Jakarta: Prenanda Media Grup.

Dasa ismaimuza. (n.d.). 2010. Pengaruh Pembelajaran Berbasis Masalah Dengan Strategi Konflik Kognitif Tterhadap Kemampuan Berpikir Kritis Matematis dan Sikap Siswa. SMP Jurnal Pendidikan Matematika,vol.4(no.1), h.2.

Elfahmi,Roni.2020. Upaya Peningkatan Kompetensi Guru Dalam Menerapkan Pembelajaran Daring Masa Pandemi Covid-19 di SMA Negeri 3 Seunangan. Bionatural Journal. Volume VII.No.2

Handarini Ika Oktavia,.2020. Pembelajaran Daring Sebagai Upaya Study From Home (SFH)

Selama Pandemi Covid-19. Jurnal Pendidikan Administrasi Perkantoran. Volume 8. Nomor 2.

Kuntaro Eko.2017. Keefektifan Model Pembelajaran Daring Dalam Perkuliahan Bahasa

Indonesia di Perguruan Tinggi. Jurnal Indonesian Language Education and Literature. Volume 3.Nomor.1

Ramadani. 2019.Metode Penerapan Metode Pembelajaran Problem Based Learning (PBL). Lantadina Journal. Volume 7. No.1

Rusman.2010.Model-modelpembelajaran. Jakarta: Gravindopersada.

Siregar, Purwanto dan Seri. 2016. Pengaruh Model Pembelajaran Problem Based Learning (pbl) Terhadap Belajar Siswa Pada Materi Pokok Suhu dan Kalor di Kelas X Semester II SMA Negeri 11 Medan t.p 2014/2015. Jurnal Ikatan Alumni Fisika Universitas Negeri Malang, vol.2(no.1), h.26.

Suciati.2020.Peningkatan Kreatifitas dan Inisiatif Guru Melalui Model Pembelajaran Daring

Pada Masa Pandemi Covid-19. Jurnal Karya Ilmiah Guru. Volume 5. Nomor 1.

Yulianti Eka dan Gunawan Indra. 2019.Model Pembelajaran Problem Based Learning (PBL) Efeknya terhadap Pemahaman Konsep dan Berpikir Kritis. Indonesian Journal of Science and Mathematics Education 